\title{
Influence of the kappa-opioid agonist RU-1205 compound in wide spread of doses on the effects of neuromediator analyzers: Bechavioral testing
}

Roman A Litvinov ${ }^{*}$, Natalya V Eliseeva ${ }^{1}$, Olesya Yu Grechko ${ }^{1}$ and Alexander A Spasov ${ }^{1,2}$

${ }^{1}$ Volgograd State Medical University, Volgograd, Russia

${ }^{2}$ Volgograd Medical Scientific Center, Volgograd, Russia

\begin{abstract}
This paper consist the information about influence of the RU-1205 compound, selective kappa-opioid agonist with analgesic action, on the effects neuromediation influenced drugs. We demonstrated that high doses (10 and $100 \mathrm{mg} / \mathrm{kg}$ ) of RU-1205 can prevent amphetamine induced effects such as hyperlocomotion, can oppress L-DOPA- and 5-OTP-induced stereotypy, can oppress the picrotoxin induced seizures and can prolong the haloperidol-induced catalepsy in mice. Herewith there were no changes in the effects of arecoline and nicotine when mice pretreated with RU-1205 compound in comparison with non pretreated mice. Additionally, there were no prevention of hypolocomotion and vegeta depressive effects of reserpine. Previously we demonstrated that RU-1205 in 1 mg/kg can oppress the amphetamine-induced hyperlocomotion and picrotoxin- and bicuculline-induced seizures, but there were no changes when RU-1205 was combined with other drugs, listed above. Taken together these dada suggests that kappa-opioid activation under the RU-1205 has a functional interaction with effects of amphetamine, L-DOPA, picrotoxin, reserpine and 5-OTP in the dose depended manner. Hypothetically, all these can be a result of kappa-opioid neuromodulation. The next stage in the mechanism of action determination, will be electrophysiological testing using patch-clamp techniques. But completely, this data suggests that RU-1205 cannot strongly modify the effects of basic non pain-sense neurotransmission analysers at the optimal analgesic doses.
\end{abstract}

Abbreviations: KOR-kappa opioid receptor, MOR-mu opioid receptor, DOR-delta opioid receptor, 5-OTP-5-oxytryptamine, L-DOPA - L- dihydroxyphenylalanine

\section{Introduction}

Well known fact that opioid neuromodulation system has a considerable role in the regulation of CNS functions, includes high integrative functions regulation, such as memory and learning, regulation of emotions and mood control, regulation of motivation, addiction and aversion, pain and sensitivity signaling pathways, control of hyperextetability of neurons and prevention of seizures [1]. So, taking together, KOR-mimetics and blockers has great therapeutical potential. The new analgesic compound creation is a one variant of pharmacological usage of the KOR activation effects. More less abuse potential and less analgesic tolerance in comparison with classical opioid analgesics, such as fentanyl or trimeperidine (promedol), is an advantage for KOR agonists $[1,2]$. One step in the way of designing the medical standards-compliant KOR analgesic is investigation the interaction of new compound with different drugs (drug-drug interaction preclinical study, the General Russian manuscript for the preclinical investigation of the new medical products under the redaction of AN Mironov, 2012). The fundamental aim of these actions is to answer the question "How does kappa-opioid activation can modify different neuromediatory system?". Another applies of the drug-drug interaction tests is to investigate the peculiar properties of the clinical management of potential analgesic because the problem of drug-drug interaction is serious especially for the central active drugs.

This paper describes the influence of a new potent analgesic and KOR-agonistic compound RU-1205 (1, 10 and $100 \mathrm{mg} / \mathrm{kg}$ ) on the behavioral effects of the following drugs: amphetamine, L-DOPA, 5-OTP, picrotoxin, haloperidol, arecoline and nicotine. There is a continuation of our previous results that RU-1205 in $1 \mathrm{mg} / \mathrm{kg}$ can oppress the effects of amphetamine and reduce the seizurogenic potential of GABA blockers such as picrotoxin and bicuculline [3]

There are different types of neuromediation that included in the transition and processing of afferent signals and associated behavior, psychic activity, locomotion and other behaviors. Neuromediators such as $5-\mathrm{HT}$, dopamine, histamine, glutamate, GABA etc. are involved and modulated by KOR. Interesting field of potential clinical management of KOR agonists usage, except opioid analgesia, is a treatment of addiction and abstinention. KOR activation oppresses the abstinentional NMDA hyperactivation (locus coeruleus) and dopamine release in ventral tegmental area when psychotropic drugs are used $[1,4,5]$. Furthermore, there is interesting potential usage of KOR activation for treating neurodegenerative diseases, such as Parkinson's disease or motoneuron disease (MND). KOR activation can prevent the NMDA-mediated depolarization in motoneurons, oppress L-DOPA-induced dyskinezia, stimulates the locomotion when monoamine depletion induced parkinsonism (reserpine-indused) $[6,7]$. In case of surgical premedication there is a combination of narcotic and antipsychotic drugs (haloperidol) can be used. Many of

Correspondence to: Roman A. Litvinov, Volgograd state medical university, Volgograd, Russia, E-mail: litvinov.volggmu@mail.ru

Key words: $R U$-1205, kappa-opioid agonist, neuromediators

Received: November 09, 2017; Accepted: November 27, 2017; Published: November 29, 2017 
these conditions require the usage of different medicinal products with neuromodulation or neuromediation activities. So, KOR activation in any respective brain regions can discharge or potentiate the effects of products specific neuromediation modify.

RU-1205 compound has an analgesic activity in wide spread of doses (0.001-100 mg/kg, ED50 $0.02 \mathrm{mg} / \mathrm{kg}$, hot-plate, mice) and in the different types of nociception models (CNS nociception models, such as hot plate and tail flick, and models of neuropathic, inflammatory and visceral pain conditions), that was shown previously [8]. Analgesic activity of the compound is mediated by the KOR activation. Additionally, RU-1205 compound doesn't activate mu- and delta-opioid receptors when in vitro (isolated tissue electroinduced contractions model) and doesn't have the typical specific adverse effects of MOR and DOR activation, such as respiratory depression, gut motility impairment, sedation or euphoric behaviors in vivo. Finally, RU1205 has a non-typical profile of KOR-associated adverse effects [8-10].

\section{Experimental procedures}

The object of study: RU-1205 compound (like a bulk, from South Federal University of Physic and Organic Chemistry, Rostovon-Don, Russia); Laboratory animals: outbreed mature white mice 20-25 g with inverted circadian rhythm. Experimental procedures were carried out from 11.00 a.m. to 16.00 p.m. Animals were handled before the testing for 3 weeks. All experiments were implemented in accordance with the requirements of Directive 2010/63/EU of the European Parliament and the Council of the European Union for the protection of animals used in Scientific purposes (22.09.2010). All experiments with narcotic substances were carried out under the license LO-34-04-000022 (12.10.2012) for working and control of spreading of narcotic drugs, psychotropic substances and precursors.

All solutions were prepared on distilled water and injected intraperitoneally. RU-1205 compound was injected in 60 minutes prior the combined drug. Time was chosen based on the pharmacokinetic properties of the compound. All data presented the effects of RU1205 in $1 \mathrm{mg} / \mathrm{kg}$ dose were recollected and compared with data from previous publication [3]. We presented the earlier results because it was needed for more complete data presentation. The number of animals in each group was $8(n=8)$.

\section{Modulation effects of neuromediator analyzers}

We studied the interactions of tested compound with the typical effects of the neurotransmitter analyzers on dopaminergic, noradrenergic, cholinergic and GABA-ergic systems. There are behavioral tests, were described in the General Manuscript of Preclinical Studying of New Drugs under the redaction of Dr. Mironov (manuscript on rus). Influence on the effects of amphetamine and reserpine were assessed by the change in locomotion (actometer Ugo Basile); influence on the effects of haloperidol - by the change in the duration of catalepsy (duration of the forced «lecturer's» pose); influence on the effects of L-DOPA -- by the hyperkinesis severity; the effects of arecoline and nicotine - by the latent time of seizures beginning; the effects of 5-OTP - by the changes in stereotypy duration.

\section{Amphetamine-indiced hyperlocomotion}

Animals were separated at the 5 groups. The treatment protocol for groups is in Table 1.

There were positive and negative control group used in this test. Positive control animals were treated with $6 \mathrm{mg} / \mathrm{kg}$ amphetamine i.p. Negative ones were injected vehicle. Ugo Basile actometer was used when quantification of locomotor activity was measured. Each animal was placed in the lactometer's box individually to indicate the full locomotion. The measurement time was 5 minutes.

\section{L-DOPA-induced stereotypy}

Animals were separated into 8 groups. The treatment protocol for groups is in Table 2 .

There were two control groups in this test. Positive control treated with $500 \mathrm{mg} / \mathrm{kg}$ of L-DOPA. This dose can provide the dyskinesia and stereotypic reactions (rering, verticalization). Negative control group treated with $200 \mathrm{mg} / \mathrm{kg}$ of L-DOPA. There is too little dose for any specific visualized reactions. Experimental groups, RU-1205 injected previously, treated with low or high doses of L-DOPA. If the compound has dopaminelythic activity, there will be a loss in L-DOPA-induced behavior or motor patterns, and vice versa for the low dose of L-DOPA and dopaminemimetic activity (including CNS monoamine reuptake inhibition or suppression of MAO or KOMT activities). Semi-quantitative scale for interpretation the results: 1 score - rare abnormal movements less than $50 \%$ of observation time; 2 scores - frequent abnormal movements $50 \%$ of the observation time; 3 scores - continuous abnormal motor acts and normal reaction to the auditory stimulus; 4 scores - continuous abnormal motor acts without reaction to the auditory stimulus.

\section{Cataleptic effect of haloperidol}

The forced "lecturer's" pose is the uncomfortable pose for mice. Healthy non cataleptic animals try to leave this pose. The control group treated with haloperidol $1 \mathrm{mg} / \mathrm{kg}$ i.p. 20 minutes before the testing. Tested groups treated with RU-1205 1, 10 or $100 \mathrm{mg} / \mathrm{kg}$ 60 minutes prior the haloperidol injection. Mice placed with front legs to the elevated platform and staying here without movements if catalepsy is developed. Cut off time was 3 minutes. There is a failure of dopamine signaling in the striatum and misbalance of dopamine/5-HT interactions when catalepsy developed [11].

\section{5-OTP-induced stereotypy}

The control and tested groups were treated with $300 \mathrm{mg} / \mathrm{kg}$ 5-OTP i.p. and registration started 10 minutes after that. Non-control animals

Table 1. Amphetamine-induced hyperlocomotion protocol.

\begin{tabular}{|c|c|c|}
\hline No. of Group & $\begin{array}{c}\text { RU-1205/dose } \\
\text { (60 min prior } \\
\text { amphetamine) }\end{array}$ & $\begin{array}{c}\text { Amphetamine } \\
\text { (30 min prior testing) }\end{array}$ \\
\hline 1 (negative control) & - (vehicle) & - (vehicle) \\
\hline 2 (positive control) & $-($ vehicle) & + \\
\hline 3 (optimal dose group) & $+/ 1 \mathrm{mg} / \mathrm{kg}$ & + \\
\hline 4 (medium-high dose group) & $+/ 10 \mathrm{mg} / \mathrm{kg}$ & + \\
\hline 5 (high dose group) & $+/ 100 \mathrm{mg} / \mathrm{kg}$ & + \\
\hline
\end{tabular}

Table 2. L-DOPA-induced stereotypy protocol.

\begin{tabular}{|c|c|c|c|}
\hline No. of group & $\begin{array}{c}\text { RU-1205/dose } \\
\text { (60 min prior } \\
\text { L-DOPA) }\end{array}$ & $\begin{array}{c}\text { L-DOPA 200 } \\
\mathbf{~ m g / k g} \\
\text { (30 min } \mathbf{~ p r i o r} \\
\text { testing) }\end{array}$ & $\begin{array}{c}\text { L-DOPA 500 } \\
\mathbf{~ m g / k g} \\
\text { (30 min } \mathbf{~ p r i o r ~} \\
\text { testing) }\end{array}$ \\
\hline 1 (low dose control) & - (vehicle) & + & - \\
\hline 2 (high dose control) & - (vehicle) & - & + \\
\hline 3 (optimal dose group) & $+/ 1 \mathrm{mg} / \mathrm{kg}$ & + & - \\
\hline 4 (medium-high dose group) & $+/ 10 \mathrm{mg} / \mathrm{kg}$ & + & - \\
\hline 5 (high dose group) & $+/ 100 \mathrm{mg} / \mathrm{kg}$ & + & + \\
\hline 6 (optimal dose group) & $+/ 1 \mathrm{mg} / \mathrm{kg}$ & - & + \\
\hline 7 (medium-high dose group) & $+/ 10 \mathrm{mg} / \mathrm{kg}$ & - & + \\
\hline 8 (high dose group) & $+/ 100 \mathrm{mg} / \mathrm{kg}$ & - & - \\
\hline
\end{tabular}


were treated with 3 different doses of RU-1205 (1, 10 or $100 \mathrm{mg} /$ $\mathrm{kg}) 60$ minutes before the 5-OTP injection, as described above. The number of head-twitches during 1 minute was calculated at the timepoints 10, 20 and 30 minutes after 5-OTP injection. The head-twitch response is a rapid side-to-side rotational head movement. The 5-OTP induces 5-HT spike and activation of 5-HT2A receptors in front lobe (prefrontal cortex) is causative for the metabolic glutamate receptors activation and head movements formation [12].

\section{Neurodepressive effects of resrpine}

Reserpine is the most nonselective monoaminergic pharmaceutical substance that was used in this investigation. This drug causes nonselective depletion of monoamines in the brain (noradrenergic, 5-HTP-ergic, dopaminergic). But well known fact that KOR activation has a potency to reduce the reserpine induced hypolocomotion [13]. We investigated influence of RU-1205 on the reserpine-induced hypolocomotion, ptosis and hypothermia. The dose of reserpine 2.5 $\mathrm{mg} / \mathrm{kg}$ was used. The protocol of testing we used is in the Table 3 .

\section{Arecoline-induced tremoris and dyskinesia}

CNS m-cholinoactivation under the arecoline can produce stereotypic behavior and dyskinetic reactions such as tremors if targeted in the dorsal striatum region (nucleus caudatus). Control and tested groups were treated with $25 \mathrm{mg} / \mathrm{kg}$ arecoline i.p. Tested animals were treated with 3 different doses of RU-1205 (1, 10 or $100 \mathrm{mg} / \mathrm{kg}) 60$ minutes before the arecoline injection.

\section{Seizurogenic reaction to nicotine}

Nicotine receptors are involved in the psychic and motor regulation. The latency of nicotine-induced motor dyscoordination, tremors and seizures is longer or shorter when receptors are blocked or activated respectively. The dose $6 \mathrm{mg} / \mathrm{kg}$, s.c. of nicotine was used. Animals were separated into 3 tested and 1 control groups. All groups were injected with nicotine after treating with different doses of RU1205 treating $(1,10$ or $100 \mathrm{mg} / \mathrm{kg})$ or vehicle in control 60 minutes prior the nicotine, and registration of the tremors and seizures latency was started immediately. The development of tremors and seizures is a quick process.

\section{Seizurogenic effect of picrotoxin}

Picrotoxin is an allosteric GABAA-blocker that induces epileptiform activity and seizures provoker. The dose $10 \mathrm{mg} / \mathrm{kg}$ s.c. of picrotoxin was used. The latency of tremor, seizures and time of the death were determined.

\section{Statistics}

Statistical analysis was completed using the Kruscal-Walles test (Dunns post-test, $<0.05$ ), ANOVA (Tukey post-test, $\mathrm{p}<0.05$ ). When choosing a statistical criterion, we estimate the normality using Kolmogorov-Smirnov test and if it is normal we used ANOVA, if not we used KruscalWalles test. The spread of mean values submitted as the standard error of mean (SEM) in all cases.

\section{Results}

Early we presented the influence of RU-1205 at $1 \mathrm{mg} / \mathrm{kg}$ on the effects of amphetamine, haloperidol, L-DOPA, arecoline, nicotine, 5 -OTP, reserpine and picrotoxin [3]. $1 \mathrm{mg} / \mathrm{kg}$ is the mean maximal effective dose of RU-1205 different nociceptive tests.

Complete information of RU-1205 influence the effects of drugs listed above is in the Table 4 . The detalisation.
Table 3. Reserpine treatment and time-point protocol.

\begin{tabular}{|c|c|c|c|}
\hline $\begin{array}{ll}\text { The effect } & \text { Dose of RU-1205, } \mathrm{mg} / \mathrm{kg} \\
\end{array}$ & 1 & 10 & 100 \\
\hline \multicolumn{4}{|l|}{ Cholinergic system } \\
\hline Arecoline-induced tremor, intensity, duration & No changes & No changes & No changes \\
\hline Nicotine-induced tremor, seizures & No changes & No changes & No changes \\
\hline \multicolumn{4}{|l|}{ GABA-ergic system } \\
\hline Picrotoxin-induced tremot, seizures & Supress & Supress & $\begin{array}{l}\text { Strong } \\
\text { Supress }\end{array}$ \\
\hline \multicolumn{4}{|l|}{ 5-HT-ergic system } \\
\hline 5-OTP-induced hyperkinesia & No changes & Supress & $\begin{array}{l}\text { Strong } \\
\text { Supress }\end{array}$ \\
\hline \multicolumn{4}{|c|}{ Monoaminergic system (predominant neurotransmitter) } \\
\hline $\begin{array}{l}\text { Amphetamine-induced hyperlocomotion } \\
\text { (dopamine) }\end{array}$ & Supress & Supress & $\begin{array}{l}\text { Strong } \\
\text { Supress }\end{array}$ \\
\hline Haloperidol-indyced cataleption (dopamine) & No changes & No changes & $\begin{array}{l}\text { Strong } \\
\text { Supress }\end{array}$ \\
\hline L-DOPA-induced hyperkinesia (dopamine) & No changes & Supress & $\begin{array}{l}\text { Strong } \\
\text { Supress }\end{array}$ \\
\hline $\begin{array}{l}\text { Reserpine-induced hypolocomotion } \\
\text { (dopamine) }\end{array}$ & $\begin{array}{c}\text { Not } \\
\text { eliminate }\end{array}$ & $\begin{array}{c}\text { Not } \\
\text { eliminate }\end{array}$ & $\begin{array}{c}\text { Not } \\
\text { eliminate }\end{array}$ \\
\hline $\begin{array}{l}\text { Reserpine-induced hypothermia, ptosis } \\
\text { (mixed) }\end{array}$ & No changes & No changes & $\begin{array}{l}\text { Strong } \\
\text { Supress }\end{array}$ \\
\hline
\end{tabular}

Table 4. Influence of RU-1205 compound on the effects of neuromediator analyzers in vivo.

\begin{tabular}{|c|c|c|c|}
\hline The effect $\quad$ Dose of $\mathrm{RU}-1205, \mathrm{mg} / \mathrm{kg}$ & 1 & 10 & 100 \\
\hline \multicolumn{4}{|l|}{ Cholinergic system } \\
\hline Arecoline-induced tremor, intensity, duration & No changes & No changes & No changes \\
\hline Nicotine-induced tremor, seizures & No changes & No changes & No changes \\
\hline \multicolumn{4}{|l|}{ GABA-ergic system } \\
\hline Picrotoxin-induced tremot, seizures & Supress & Supress & $\begin{array}{l}\text { Strong } \\
\text { Supress }\end{array}$ \\
\hline \multicolumn{4}{|l|}{ 5-HT-ergic system } \\
\hline 5-OTP-induced hyperkinesia & No changes & Supress & $\begin{array}{l}\text { Strong } \\
\text { Supress }\end{array}$ \\
\hline \multicolumn{4}{|c|}{ Monoaminergic system (predominant neurotransmitter) } \\
\hline $\begin{array}{l}\text { Amphetamine-induced hyperlocomotion } \\
\text { (dopamine) }\end{array}$ & Supress & Supress & $\begin{array}{l}\text { Strong } \\
\text { Supress }\end{array}$ \\
\hline Haloperidol-indyced cataleption (dopamine) & No changes & No changes & $\begin{array}{l}\text { Strong } \\
\text { Supress }\end{array}$ \\
\hline L-DOPA-induced hyperkinesia (dopamine) & No changes & Supress & $\begin{array}{l}\text { Strong } \\
\text { Supress }\end{array}$ \\
\hline $\begin{array}{l}\text { Reserpine-induced hypolocomotion } \\
\text { (dopamine) }\end{array}$ & $\begin{array}{c}\text { Not } \\
\text { eliminate }\end{array}$ & $\begin{array}{c}\text { Not } \\
\text { eliminate }\end{array}$ & $\begin{array}{c}\text { Not } \\
\text { eliminate }\end{array}$ \\
\hline $\begin{array}{l}\text { Reserpine-induced hypothermia, ptosis } \\
\text { (mixed) }\end{array}$ & No changes & No changes & $\begin{array}{l}\text { Strong } \\
\text { Supress }\end{array}$ \\
\hline
\end{tabular}

\section{Influence on the hyperlocomotor effect of amphetamine}

Mean spontaneous locomotion in positive control group was at two fold than in negative control. RU-1205 oppressed hyperlocomotor effect of amphetamine in dose-dependent manner (Table 5).

$1 \mathrm{mg} / \mathrm{kg}$ of RU-1205 induced reduction of hyperlocomotion about $40 \%$ of amphetamine treated only group. The oppression of hyperlocomotion in 10 and $100 \mathrm{mg} / \mathrm{kg}$ of RU-1205 pretreated mice was $65 \%$ and $80 \%$ respectively less in comparison the positive control group.

\section{Influence on the L-DOPA stereotypy}

The low dose control group didn't present any symptoms of abnormal behaviors. In comparison the high dose of L-DOPA caused a severe dyskinesia and high-dopamine-assoxiated behavior (Table 6). 
Table 5. Influence of RU-1205 on the hyperlocomotor effect of amphetamine. Note * Significant in comparison with the negative control; \# - Significant in comparison with the positive (amphetamine treated only) control (Kruskal-Wallis one-way analysis of variance, Dunn's post-test, $\mathrm{p}<0,05)$.

\begin{tabular}{|c|c|}
\hline No. of Group & Locomotor activity $(\mathbf{M} \pm$ SEM) \\
\hline 1 (negative control) & $133,1 \pm 12,3$ \\
\hline 2 (control) & $265,2 \pm 13,7^{*}$ \\
\hline $3(1 \mathrm{mg} / \mathrm{kg}$ dose group) & $240,0 \pm 35,3^{*}$ \\
\hline $4(10 \mathrm{mg} / \mathrm{kg}$ dose group) & $120,8 \pm 13,1 \#$ \\
\hline $5(100 \mathrm{mg} / \mathrm{kg}$ dose group) & $53,7 \pm 9,0 \#$ \\
\hline
\end{tabular}

Table 6. Influence of RU-1205 on the dyskinetic effect of L-DOPA (scores, M \pm SEM). Note * - Significant in comparison with the low dose control; \# - Significant in comparison with the high dose control (ANOVA, Tukey post-test, $\mathrm{p}<0,05$ ).

\begin{tabular}{|c|c|c|}
\hline No. of group & $\begin{array}{c}\text { Abnormal movements } \\
\text { when low dose of L-DOPA }\end{array}$ & $\begin{array}{c}\text { Abnormal movements } \\
\text { when high dose of L-DOPA }\end{array}$ \\
\hline 1 (low dose control) & $0.4 \pm 0.1$ & - \\
\hline 2 (high dose control) & - & $4.0 \pm 0.0^{*}$ \\
\hline 3 (RU-1205 $1 \mathrm{mg} / \mathrm{kg}$ ) & $0.3 \pm 0.2$ & $3.2 \pm 0.1^{*}$ \\
\hline 4 (RU-1205 $10 \mathrm{mgkg})$ & $0.0 \pm 0.0$ & $1.1 \pm 0.2 \#$ \\
\hline 5 (RU-1205 $100 \mathrm{mg} / \mathrm{kg})$ & $0.0 \pm 0.0$ & $0.3 \pm 0.2 \#$ \\
\hline
\end{tabular}

So, there was strong depression of L-DOPA dyskinetic effect by RU-1205 and no potentiating.

\section{Influence on the cataleptic effect of haloperidol}

The mean latency of leave the forced pose was $93.7 \pm 15.7$ seconds in the control haloperidol treated animals. Early we determined that RU-1205 $1 \mathrm{mg} / \mathrm{kg}$ cannot modify the haloperidol-induced catalepsy. The dose $10 \mathrm{mg} / \mathrm{kg}$ had no significant effect too but tendented to grownment without significance. The maximal dose of RU-1205 (100 $\mathrm{mg} / \mathrm{kg}$ ) caused strong prolongation of catalepsy (Table 7).

\section{Influence on the effects of 5-OTP}

Head twitches were observed in control animals treated with $300 \mathrm{mg} / \mathrm{kg}$ 5-OTP. RU-1205 $1 \mathrm{mg} / \mathrm{kg}$ didn't discharge the number of twitches in the group in comparison with control. The reduction of twitches at $10 \mathrm{mg} / \mathrm{kg}$ and $100 \mathrm{mg} / \mathrm{kg}$ of RU-1205 was too much (Figure 1).

\section{Influence on the neurodepressive effects of reserpine}

In the control group of animals (reserpine treated only) there were hypolocomotion (96.2\% oppression of locomotion in comparison with the nontreated animals,), rectal hypothermia (mean temperature loss around $2.2^{\circ} \mathrm{C}$ ), and ptosis (mean eye gap around $1.4 \pm 0.6 \mathrm{~mm}$ ). Detalisation is in the Table 8 and 9.

There were no significant differences in the locomotion between the groups, treated with combination of 1,10 or $100 \mathrm{mg} / \mathrm{kg}$ of RU1205 and $2.5 \mathrm{mg} / \mathrm{kg}$ of reserpine and $2.5 \mathrm{mg} / \mathrm{kg}$ of reserpine alone. There were determined that no significant differences between rectal temperature of reserpine only treated group and tested groups RU12051 and $10 \mathrm{mg} / \mathrm{kg}$ treated groups. When $100 \mathrm{mg} / \mathrm{kg}$ of RU-1205 treated group there was deeper opression of the rectal temperature (9.1\% loss in comparison with reserpine).

\section{Influence on the effects of arecoline}

In the arecoline treated only control group it was tremor with latency 67.3 \pm 9.0 seconds and duration 1107.0 \pm 59.6 seconds. RU-1205 didn't modify the effects of arecoline (data are not presented, KruscalWallis test, Dunn's post-test).

\section{Interaction with the effects of nicotine}

In the nicotine only treated animals tremor with mean latency $61.0 \pm 5.1$ seconds and seizures with latency $100.5 \pm 4.4$ seconds were investigated. There were no significand differences between the control group and RU-1205 pretreated groups (data are not presented, KruscalWallis test, Dunn's post-test).

\section{Influence on the effects of picrotoxin}

In the control group there were $253.3 \pm 41.5$ seconds of tremor latency and $368.2 \pm 56.3$ seconds of seizures latency. The mean number of seizures was $24.0 \pm 4.2$. We calculated only tonic-clonic seizures with body overturning. The mean time of the dead after injection of picrotoxin was $860.0 \pm 90.2$ seconds. There was no significant effect of RU-1205 compound in the dose $1 \mathrm{mg} / \mathrm{kg}$, but there were significant (Kruskal-Wallis test, Dunns post-test, $\mathrm{p}<0.05$ ) in $10 \mathrm{mg} / \mathrm{kg}$ (duration of the tremor latency was $40 \%$ longer) and $100 \mathrm{mg} / \mathrm{kg}$ (prolongation of adventition time for all marked conditions, at 2.5 times for the tremor latency, at 6 times for the seizures latency, at 6.4 for the number of seizures, and at 2.4 times for dead time).

Table 7. Influence of RU-1205 on the cataleptic effect of haloperidol (M \pm SEM). Note: * - Significant in comparison with the control (Kruskal-Wallis one-way analysis of variance, Dunn's post-test, $\mathrm{p}<0,05$ )

\begin{tabular}{|c|c|}
\hline No. of group/ dose of RU-1205 & Locomotion \\
\hline 1 (negative control) & $133.1 \pm 2.3$ \\
\hline 2 (reserpine treated only control) & $5.1 \pm 0.7^{*}$ \\
\hline 3 (RU-1205 $1 \mathrm{mg} / \mathrm{kg})$ & $3.7 \pm 1.2^{*}$ \\
\hline 4 (RU-1205 $10 \mathrm{mg} / \mathrm{kg})$ & $30.1 \pm 0.5^{*} \#$ \\
\hline 5 (RU-1205 $100 \mathrm{mg} / \mathrm{kg})$ & $1.2 \pm 0.8^{*}$ \\
\hline
\end{tabular}

Table 8. Influence RU-1205 compound on the hypolocomotor effects of reserpine (M \pm SEM). Note: *- significant in comparison with the negative control; significant in comparison with reserpine treatedonly group (ANOVA, post-test Tukey, $\mathrm{p}<0.05$ ).

\begin{tabular}{|c|c|}
\hline No. of group/ dose of RU-1205 & Locomotion \\
\hline 1 (negative control) & $133.1 \pm 2.3$ \\
\hline 2 (reserpine treated only control) & $5.1 \pm 0.7^{*}$ \\
\hline 3 (RU-1205 $1 \mathrm{mg} / \mathrm{kg})$ & $3.7 \pm 1.2^{*}$ \\
\hline 4 (RU-1205 $10 \mathrm{mg} / \mathrm{kg})$ & $30.1 \pm 0.5^{*} \#$ \\
\hline $5(\mathrm{RU}-1205100 \mathrm{mg} / \mathrm{kg})$ & $1.2 \pm 0.8^{*}$ \\
\hline
\end{tabular}

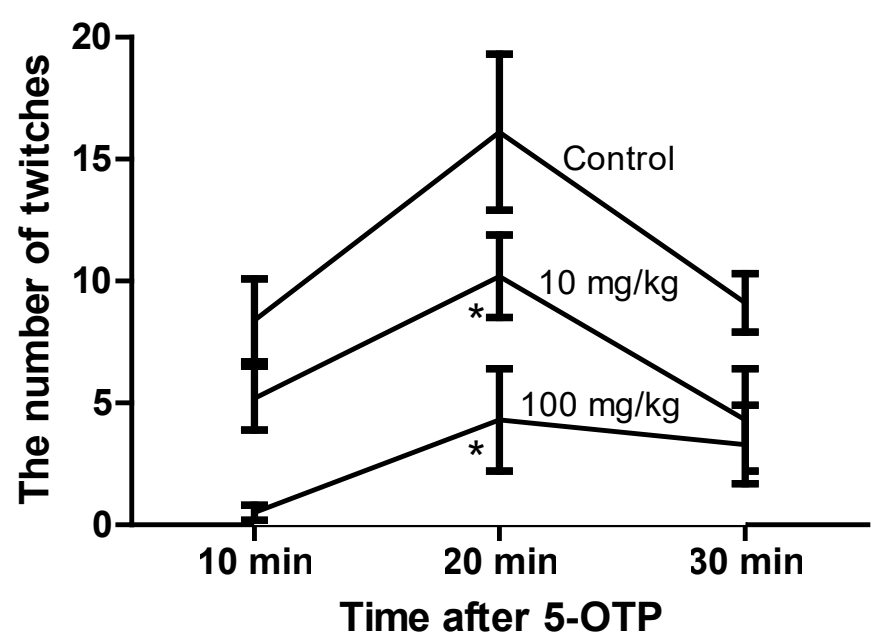

Figure 1. The influence of RU-1205 on the 5-OTP-induced head twitching $(\mathrm{M} \pm \mathrm{SEM})$ Note: *-significant in comparison with the control (ANOVA, post-test Tukey, $\mathrm{p}<0.05$ ). Dose $1 \mathrm{mg} / \mathrm{kg}$ RU-1205 is not presented on the graph for the better clarity. 
Table 9. Influence RU-1205 compound on the reserpine-induced hypothermia and ptosis $(\mathrm{M} \pm \mathrm{SEM})$.

\begin{tabular}{|c|c|c|c|c|c|c|}
\hline \multirow[b]{2}{*}{ No. of group } & \multicolumn{3}{|c|}{ Temperature } & \multicolumn{3}{|c|}{ Ptosis } \\
\hline & Before reserpine & $\begin{array}{c}4 \text { hours after, } \\
\text { RU-1205 injection time } \\
\text { point }\end{array}$ & $\begin{array}{l}30 \text { minutes after RU- } \\
1205 \text { injection }\end{array}$ & Before reserpine & $\begin{array}{c}4 \text { hours after, } \\
\text { RU-1205 injection time } \\
\text { point }\end{array}$ & $\begin{array}{l}30 \text { minutes after RU- } \\
1205 \text { injection }\end{array}$ \\
\hline 1 (negative control) & $37.8 \pm 0.3$ (vehicle) & $37.5 \pm 0.5$ (vehicle) & $37.3 \pm 0.3$ (vehicle) & $\begin{array}{l}3.0 \pm 0.0 \\
\text { (vehicle) }\end{array}$ & $3.0 \pm 0.0$ (vehicle) & $3.0 \pm 0.0($ vehicle $)$ \\
\hline 2 (reserpine treated only) & $38.2 \pm 0.4$ & $35.5 \pm 0.5^{*}($ vehicle $)$ & $35.3 \pm 0.7$ (vehicle) & $3.0 \pm 0.0$ & $1.2 \pm 0.4^{*}($ vehicle $)$ & $1.4 \pm 0.6^{*}($ vehicle $)$ \\
\hline $3(1 \mathrm{mg} / \mathrm{kg})$ & $38.4 \pm 0.3$ & $35.5 \pm 0.5^{*}$ & $35.4 \pm 0.9^{*}$ & $3.0 \pm 0.0$ & $1.1 \pm 0.4^{*}$ & $1.5 \pm 0.5^{*}$ \\
\hline $4(10 \mathrm{mg} / \mathrm{kg})$ & $38.4 \pm 0.3$ & $35.5 \pm 0.7^{*}$ & $35.0 \pm 1.4^{*}$ & $3.0 \pm 0.0$ & $0.5 \pm 0.1^{*}$ & $0.8 \pm 0.2^{*}$ \\
\hline $5(100 \mathrm{mg} / \mathrm{kg})$ & $38.0 \pm 0.5$ & $34.5 \pm 0.5^{*}$ & $32.1 \pm 0.2^{* \#}$ & $3.0 \pm 0.0$ & $0.6 \pm 0.2^{*}$ & $0.0 \pm 0.0^{* \#}$ \\
\hline
\end{tabular}

\section{Discussion}

The effects of KOR activation under the KOR agonist RU-1205 compound are similar as under the classical KOR agonists, such as U-50,488H or U-62,066E (spiradoline). Dopamine levels in dorsal and ventral striatal areas and ventral tegmental area (VTA) are loss when KOR is activated. The L-DOPA associated behavioral disruptions we observed when high dose of L-DOPA given, generally associated with dopamine overload caused by L-DOPA, cabergoline etc. [14]. Additionally effective medical management of L-DOPA-induced dyskinesia remains an unmet need for patients with Parkinson disease $[4,5]$. There are no data that KOR activation and subsequent dopamine suppression causatives for iatrogenic parkinsonism in healthy subjects (however, KOR activation worsens parkinsonism with dyskinesia reduction in experimental model of $\mathrm{SN}$ degeneration in primates when L-DOPA-induced dyskinesia) [7]. Changes in opioid transmission in the basal ganglia suggest a therapeutic opportunity when dopapinemimetic dyskinesia. So, we determined that pretreatment with RU-1205 can prevent L-DOPA-induced stereotypy and dyskinesia. There is typical effect of KOR activation. Moreover, strong enough effect of dyskinesia suppression was observed only in $10 \mathrm{mg} / \mathrm{kg}$ and more and not detected in our previous study with $1 \mathrm{mg} / \mathrm{kg}$. Previously we reported that $10 \mathrm{mg} /$ $\mathrm{kg}$ of RU-1205 is not a dangerous dose for usage $(1 \mathrm{mg} / \mathrm{kg}$ is maximal analgesic dose). Only mild hypothermia and no any other adverse reactions are developed when $10 \mathrm{mg} / \mathrm{kg}$ i.p. [10]. So, the potential usage of the compound in different doses may have different appointments. This is an interesting remark.

Dorsal striatal region and substantia nigra are motor coordinators. In comparison ventral part of striatum plays a role in the mood and motivation regulation. And this area is regulated by KOR neuromodulation too. There is a part of reward system. KOR activation is produces dopamine loss in VTA and ventral striatum [4,5]. Mesolimbic and mesocortical pathways are two main outputs from VTA: Both are dopaminergic and KOR-regulated. Both pathways are activates by acute treatment with amphetamine. At the 1, 10 and 100 $\mathrm{mg} / \mathrm{kg}$ of RU- 1205 decrease of amphetamine-induced hyperlocomotion was about $40 \%, 65 \%$ and $80 \%$ less than in amphetamine treated only group. In the case of $10 \mathrm{mg} / \mathrm{kg}$, the absolute level of spontaneous locomotion was around negative control values. In the case of 100 $\mathrm{mg} / \mathrm{kg}$ RU-1205, the absolute values of mean locomotion were at 2.5 times less, than in negative control group. In results, we determined that kappa-opioid agonist RU-1205 can oppress the locomotor effect of amphetamine. This is associated with contraversion of dopamine levelup in the mesolymbic pathway when KOR is activated. There is a typical effect of KOR activation too.

The next inherent ability of KOR agonists is potentiation of haloperidol-induced catalepsy. Basically, opioids and neuroleptic drugs potentiate the effects of each other. Prolongation of analgesia and risk of haloperidol overload are may be observed when both products are combined. There was shown the potentiation of catalepsy duration as a tendention when $10 \mathrm{mg} / \mathrm{kg}$ and strong significant when $100 \mathrm{mg} / \mathrm{kg}$. The catalepsy is a result of striatal dopamine loss and 5-HT misbalance. There is third typical effect of KOR activation. Interestingly, that RU-1205 cannot induce the own cataleptic effect at the doses 0.1$100 \mathrm{mg} / \mathrm{kg}$.

Based this three tests we can conclude that influence of KOR activation under the RU-1205 is much more lower in motor striatum (putamen, nucleus caudatus) than in ventral part of the striatum (nucleus accumbens) and VTA.

Coadministration of reserpine and RU-1205 gave an expected result. There was partially discharge of hypolocomotion. This is consistent with the expected profile of a KOR agonist. KOR activation can to reduce reserpine-induced hypolocomotion [13]. We determined that $1 \mathrm{mg} / \mathrm{kg}$ of RU-1205 was ineffective. This is correlates with our previous results. Dose $10 \mathrm{mg} / \mathrm{kg}$ was effective and reduced the hypolocomotor effect of reserpine. But the next, the sedative effect at highest dose probably underlies the bell-shaped nature of the dose response curve for locomotor stimulation by RU-1205. Previously we determined that hypolosomotion is can be an own effect of RU-1205 but in doses too high than maximal analgesic $1 \mathrm{mg} / \mathrm{kg}(20 \mathrm{mg} / \mathrm{kg}$ and more). The locomotor-stimulant effect of RU-1205 in the present study may in part be due to effects in the output regions of the basal ganglia. However, activation of KOR in the striatum inhibits the release of glutamate from striatal nerve terminals. Additionally, the activation of locomotion by RU-1205 might also be due to an effect on glutamate transmission in the striatum (inputs from the front lobes). Reserpine depress basic monoaminergic transmittions (dopamine, 5-HT, noradrenalin) and can reduce the body temperature. We determined that there were no significant differences between rectal temperature of animals, treated with reserpine only and combined with RU-1205 $1 \mathrm{mg} / \mathrm{kg}$ or $10 \mathrm{mg} / \mathrm{kg}$. But there was a loss of body temperature $9.1 \%$ in comparison with reserpine treated only when dose $100 \mathrm{mg} / \mathrm{kg}$ was used. This was expected [15]. The hypothermic results and assumptions about its mechanistic are described in our previous paper [10].

5-OTP is the next monoamine analyzer and an immediate precursor of 5-HT. This paper we determined the oppression of 5-OTP-induced twitches under the RU-1205 activation. The mechanism of twitches is complicated. The main role in this stereotypy formation is gives to the 5-HT-glutamate interactions in the front lobes $[16,17]$. There is not only 5-OTP can induce this activity but activation of metabolic glutamatergic receptors is needs for this reaction. The concept of KOR neuromodulation shows that KOR activation can suppress glutamatergic postsynaptic potentiation thru the suppression of glutamate release. The KOR mechanism of neuromodulation includes the suppression of 5-HT release in many regions, such as raphe nuclei and suppression of glutamate in the prefrontal cortex. So, there is no possible to summarize the hypothetical mechanism of action of 
RU-1205 (glutamatergic, 5-HT-ergic or both) in this case. But there is interesting question: 1) head-twitching is a hallucinogene-specific reaction for 5 -HT stimulators; 2) KOR activation can produce the own psychotic effect in some cases; 3 ) is KOR activation can prevent 5-HT-induced psychosis induced by some narcotics such as LSD? This assumption of KOR activation usage is in opposition to the main clinical observations that KOR activation induces own hallucinogenic reaction. So, the suppression of head-twitches formation and hallucinogenic action simultaneously - there is a new challenge for KOR investigators [18].

The next analyzers we used were cholinergic substances nicotine and arecoline. There are no influence of RU-1205 on the effects of this analyzers were observed. Administration of the muscarinic cholinoreceptor agonist arecoline to mice induces long-lasting tremor. The mechanism of pathogenesis of arecoline tremor predominantly involves NMDA-receptors. Moderate blockade of AMPA-type receptors could potentiate the preventive effect of mixed-action antagonists (anti-NMDA+anti-AMPA), though predominance of blocking action against AMPA-type receptors prevented this effect [19]. The previous paragraph we discussed about KOR-mediated prevention of glutamate neuroexcitability. But this findings suggests that there no influence of KOR activation on the effect of arecoline. Why? There is assumption that KOR is involved in the glutamate-induced reactions regulation independly from $\mathrm{m}$-cholinergic reactions. In the last, it was shown that KOR activation can prevent the pilocarpine-induced tremoris and seizures, but the same anticholinergic activity was not observed for RU-1205 in the current study [18]. The same situation is developed around influence of RU-1205 on the acute nicotine-induced tremor. The last finding suggests that nicotine-induced tremor's mechanism of development involves 5-HT neuromediation [20]. There are 5-HT1A and 5-HT2A receptors can to potentiate and attenuate this tremor respectively, if activated by selective agonists. The reduction of 5-OTP twitches, observed previously, is in opposition with our current findings. Current findings suggest that there are different mechanisms of regulation of 5-HT release in KOR-associated suppression of headtwitches and nicotine-induced tremoris. So, KOR regulation is not involved or involved otherwise in the nicotine-induced tremor than in 5-OTP-induced stereotypy despite both reactions are 5-HT-dependent ultimately.

And the last analyzer is picrotoxin. There is a typical action of KOR activators to reduce the seizures, induced by GABAA blockers when both single treatment and kindling model [21]. Electrophysiological, biochemical and pharmacological data support the hypothesis that dynorphin is implicated in specific types of seizures. There is clear evidence that this is true for complex partial (limbic) seizures, i.e. those characteristic of temporal lobe epilepsy, because; (1) dynorphin is highly expressed in various parts of the limbic system, and particularly in the granule cells of the hippocampus; (2) dynorphin appears to be released in the hippocampus (and in other brain areas) during complex partial seizures; (3) released dynorphin inhibits excitatory neurotransmission at multiple synapses in the hippocampus via activation of kappa opioid receptors; (4) kappa opioid receptor agonists are highly effective against limbic seizures. Data on generalised tonic-clonic seizures are less straightforward. Picrotoxin is a seizurogenic compound, realizing its effect trough systems, includind limbic system. Additionally, KOR system of substantia nigra plays an important role in the activation of the antiepileptic system and limitation of picrotoxin-induced seizures [22].

In conclusion, we determined the influence of novel kappa-opioid compound on the effects of neuromediator analyzers (activators and blockers). We detected that kappa-opioid activation under the
RU-1205 has a functional interaction with effects of amphetamine, L-DOPA, picrotoxin, reserpine and 5-OTP in the dose depended manner. Hypothetically, all these can be a result of kappa-opioid neuromodulation. The next stage in the mechanism of action determination, will be electrophysiological testing using patch-clamp techniques. But completely, this data suggests that RU-1205 cannot strongly modify the effects of basic non pain-sense neurotransmission analysers at the optimal analgesic doses.

\section{Acknowledgements}

The corresponding author (Dr. Litvinov) thanks to Daria D. Shamshina (VolSMU, Volgograd, Russia) for the inspiration and support when the text prepared and experiments carried out.

\section{References}

1. Pasternak GW (2011) Opiate receptors. NJ: Humana Press p. 497.

2. Chavkin C (2011) The Therapeutic Potential of Opioids for Treatment of Pain and Addiction. Neuropsychopharmacology 36: 369-370.

3. Spasov AA, Grechko OY, Shtareva DM, Rashchenko AI (2014) Study of the interaction of RU-1205 with neurotransmitter analyzers. J Volg SMU 50: 120-122.

4. Cahill CM, Taylor AMW, Cook C, Ong E, Morón J A, et al. (2014) Does the kappa opioid receptor system contribute to pain aversion. Front Pharmacol 5: 253.

5. Land BB, Bruchas MR, Schattauer S, Giardino WJ, Aita M, et al. (2009) Activation of the kappa opioid receptor in the dorsal raphe nucleus mediates the aversive effects of stress and reinstates drug seeking. Proc Natl Acad Sci U S A 106: 19168-19173. [Crossref]

6. Potts LF, Park ES, Woo JM, Dyavar Shetty BL, Singh A, et al. (2015) Dual к-agonist/ $\mu$-antagonist opioid receptor modulation reduces levodopa-induced dyskinesia and corrects dysregulated striatal changes in the nonhuman primate model of Parkinson disease. Ann Neurol 77: 930-941.

7. Cox H, Togasaki DM, Chen L, Langston JW, Di Monte DA, et al. (2007) The selective kappa-opioid receptor agonist U50,488 reduces L-dopa-induced dyskinesias but worsens parkinsonism in MPTP-treated primates. Exp Neurol 205: 101-107.

8. Grechko OY, Litvinov RA, Spasov AA, Rashchenko AI, et al. (2017) Study of $\hat{1}^{1 / 4}$ - and $\hat{I}^{\prime}$-Opioid Activities in Agents with Various $\hat{I}^{\circ}$-Receptor Selectivity. Bull Exp Biol Med 162: 632-635. [Crossref]

9. Grechko OY, Eliseeva NV, Spasov AA, Litvinov RA (2016) Analgetic Activity of a Benzimidazole Derivative on Models of Inflammatory Pain. J Volg SMU 58: 101-103.

10. Spasov AA, Grechko OY, Eliseeva NV, Litvinov RA, Shamshina DD (2017) Toxic Effect of Single Treatment with Kappa-Opioid Agonist, Ru-1205 Compound, on the Neurological Status of Wild Type Mice. J Clin Pharm 3: 1014.

11. Reavill C, Kettle A, Holland V, Riley G, Blackburn TP (1999) Attenuation of haloperidol-induced catalepsy by a 5-HT2C receptor antagonist. Br J Pharmacol 126 : 572-574.

12. Moreno JL, Holloway T, Albizu L, Sealfon SC, González-Maeso J (2011) Metabotropic glutamate mGlu2 receptor is necessary for the pharmacological and behavioral effects induced by hallucinogenic 5-HT2A receptor agonists. Neurosci Lett 493: 76-79.

13. Hill MP, Brotchie JM (1999) The adrenergic receptor agonist, clonidine, potentiates the anti-parkinsonian action of the selective kappa-opioid receptor agonist, enadoline, in the monoamine-depleted rat. Br J Pharmacol 128: 1577-1585.

14. Encarnacion EV, Hauser RA (2008) Levodopa-induced dyskinesias in Parkinson's disease: etiology, impact on quality of life, and treatments. Eur Neurol 60: 57-66. [Crossref]

15. Baker AK, Meert TF (2002) Functional effects of systemically administered agonists and antagonists of mu, delta, and kappa opioid receptor subtypes on body temperature in mice. J Pharmacol Exp Ther 302: 1253-1264. [Crossref]

16. González-Maeso J, Ang R, Yuen T, Chan P, Weisstaub NV, et al. (2008) Identification of a Novel Serotonin/Glutamate Receptor Complex Implicated in Psychosis. Nature 452: 93-97.

17. Tao R, Auerbach SB (2002) Opioid receptor subtypes differentially modulate serotonin efflux in the rat central nervous system. J Pharmacol Exp Ther 303: 549-556.

18. Przewlocka B, Machelska H, Lason W (1994) Kappa opioid receptor agonists inhibit the pilocarpine-induced seizures and toxicity in the mouse. Eur Neuropsychopharmacol 4: $527-533$. 
19. Lukomskaya NY, Lavrent'eva VV, Starshinova LA, Zhabko EP, Gmiro VE, et al. (2008) Involvement of ionotropic glutamate receptors in the appearance of arecoline tremor in mice. Neurosci Behav Physiol 38: 421-426.

20. Kunisawa N, Iha HA, Nomura Y, Onishi M, Matsubara N, et al. (2017) Serotonergic modulation of nicotine-induced kinetic tremor in mice. J Pharmacol Sci 134: 131-138. [Crossref]
21. Kryzhanovskii GN, Shandra AA, Godlevskii LS, Mazarati AM, Nguyen TT (1991) The role of the opiate mechanisms of the hippocampus and substantia nigra in the behavioral and convulsive disorders in picrotoxin-induced kindling. Article in Russian. Biull Eksp Biol Med 111: 235-239.

22. Simonato M, Romualdi P (1996) Dynorphin and epilepsy. Prog Neurobiol 50: 557-583. [Crossref]

Copyright: (C2017 Litvinov RA. This is an open-access article distributed under the terms of the Creative Commons Attribution License, which permits unrestricted use, distribution, and reproduction in any medium, provided the original author and source are credited. 